\title{
miR-30c may serve a role in endometriosis by targeting plasminogen activator inhibitor-1
}

\author{
XIAOLI CHEN $^{1 *}$, YAN JIANG $^{2 *}$ and DIANLING PAN ${ }^{3}$

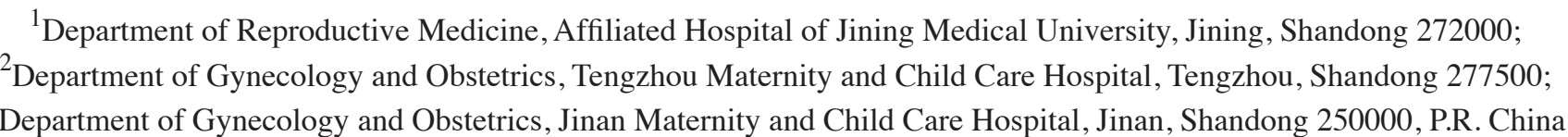

Received July 23, 2015; Accepted October 28, 2016

DOI: $10.3892 / \mathrm{etm} .2017 .5145$

\begin{abstract}
The present study aimed to investigate the role of miR-30c in endometriosis (EMs) and the underlying mechanism. The expression of miR-30c and plasminogen activator inhibitor type 1 (PAI-1) mRNA in EMs tissues was detected by reverse transcription-quantitative polymerase chain reaction (RT-qPCR) and the expression of PAI-1 protein was detected by western blot analysis. The proliferation, migration, invasion and adhesion of endometrial stromal cells (ESCs) in different groups transfected with miR-30c mimic or inhibitor were compared. It was demonstrated that miR-30c expression in ectopic and eutopic endometriosis tissues were significantly lower than in normal endometrial tissue. However, PAI-1 mRNA expression in ectopic and eutopic endometrial tissues was higher than in normal endometrial tissues. Furthermore, the expression of PAI-1 protein was higher in ectopic and eutopic endometrosis tissues than in normal tissues. RT-qPCR results indicated that miR-30c expression was significantly increased or decreased in ESCs following transfection of mimic or inhibitor of miR-30c, respectively. Overexpression of miR-30c repressed the expression of PAI-1 mRNA and protein, while inhibition of miR-30c upregulated the expression of PAI-1 in ESCs. In addition, the invasion, migration, proliferation and adhesion of ESCs was repressed following the overexpression of miR-30c, whereas they were promoted when miR-30c expression was downregulated. The results of the present study indicated that miR-30c serves an important role in the development and progression of EMs by regulating the expression of PAI-1.
\end{abstract}

Correspondence to: Professor Dianling Pan, Department of Gynecology and Obstetrics, Jinan Maternity and Child Care Hospital, 2 Jianguo Xiaojing 3rd Road, Middle, Jinan, Shandong 250000, P.R. China

E-mail: sdl1333@163.com

${ }^{*}$ Contributed equally

Key words: endometriosis, miR-30c, plasminogen activator inhibitor-1

\section{Introduction}

Endometriosis (EMs) is characterized by the growth of endometrial glands and stroma outside the uterine cavity and is a common disease among women of childbearing age (1). EMs affects 6-10\% fertile women and may cause abdominal pain and decreased fertility and its recurrence rate is slightly higher than its incidence rate (2). EMs can migrate to distant tissues, including the peritoneum, ovarian and inteestinal walls (3). Although EMs is a benign disease, it has malignant capabilities (4).

MicroRNAs (miRNAs) are a class of endogenous and highly evolutionarily conserved non-coding RNAs of 18-24 nucleotides in length $(5,6)$. miRNA can induce mRNA degradation or the translational repression of target genes through complementary pairing with the $3^{\prime}$ untranslated region (UTR) of target mRNA (7). It has been demonstrated that miRNA serves a variety of roles in physiological processes, including growth, differentiation, proliferation and apoptosis (8-10). In addition, miRNA can change the physiological and biological characteristics of the endometrium by targeting multiple genes $(11,12)$. Therefore, differences in the miRNA expression profile between patients with and those without EMs may indicate associations with the development of EMs. Previous studies have demonstrated that miR-30c may be involved in the progression of numerous diseases, including the regulation of plasminogen activator inhibitor (PAI) in sickle cell anemia (13), the reorganization of myocardial connective tissue in myocardial infarction (14), adipocyte differentiation in diabetes (15), inhibition of the invasion of non-small cell lung cancer (16) and promotion of the toxicity of natural killer cells to inhibit the development of liver cancer (17). It has been reported that miR-30c negatively regulates endometrial cancer cells by repressing the metastasis-associated gene-1 (MAG-1) (18). However, the role of miR-30c in EMs has not yet been assessed.

PAI type 1 (PAI-1) belongs to the serine protease inhibitor superfamily and is single-chain glycoprotein composed of 379 or 381 amino acids, with a molecular mass of $50 \times 10^{3} \mathrm{Da}(19,20)$. PAI-1 protein is unstable as it does not contain a disulfide bond; however, it can become stable by combining with vitronectin $(19,21)$. PAI-1 has three types of structures; an active, inactive and unstable type, and its conformation can 
be mutually transformed $(19,22)$. PAI-1 is widely expressed in various cell types, including platelets, monocytes, megakaryocytes, liver cells, mesangial cells, fibroblasts and basal cells in adipose tissue (23). In addition, vascular smooth muscle cells and endothelial cells are the primary producers of PAI-1 (19). Secreted PAI-1 can enter the stromal cells or blood circulation and certain PAI-1 proteins in circulating blood can be stored in the $\alpha$ particles of platelets, while others present in plasma serve important physiological functions (24). PAI-1 has an important regulatory role in the fibrinolytic system and the coagulation system, which is the primary inhibitor of the fibrinolytic system, to suppress urinary plasminogen activator/tissue plasminogen activator activity and to block the conversion of plasminogen to plasmin (25). Furthermore, PAI-1 serves an important role in cell signaling, adhesion and metastasis (26). PAI-1 can inhibit fibrinolysis, stabilize the extracellular matrix and promote invasion $(27,28)$. It has been demonstrated that PAI-1 may stabilize the basement membrane by inhibiting protein degradation in a number of physiological processes, including the evolution of connective tissue, blood coagulation, fibrinolysis, complement activation, inflammatory overreaction and tumor angiogenesis and stability (29-31).

The development and progression of EMs includes numerous steps, including cell adhesion, invasion and angiogenesis (4). In the present study, the expression of miR-30c and PAI-1 in EMs was measured and the role of miR-30c and PAI-1 in EMs was analyzed.

\section{Materials and methods}

Patients and samples. The present study included 20 female patients with EMs who were admitted to the Department of Gynaecology and Obstetrics of the Affiliated Hospital of Jining Medical University (Jining, China) between May 2013 and December 2014. Their eutopic and ectopic endometrium were collected. As a control, normal endometrial tissues were collected from 18 female patients with primary cervical cancers who had undergone complete hysterectomy. The average age of patients with EMs was $(43 \pm 2.4$ years) and that of the control group was $(41 \pm 3.3$ years); there were no significant differences between two groups with regard to age. All patients experienced regular menses and the endometrium was in the secretory phase (confirmed by menstrual cycle and histological examination). Only patients who had not received any hormone treatment and who had not experienced any serious complications in the three months preceding surgery were included in the present study. Prior written and informed consent was obtained from every patient and the study was approved by the ethics review board of the Affiliated Hospital of Jining Medical University (Jining, China).

Isolation and culture of primary endometrial stromal cells (ESCs). ESCs were isolated from endometrial tissues. In brief, following rinsing 2-3 times with phosphate-buffered saline (PBS), endometrial tissue was cut into $0.5-1 \mathrm{~mm}^{3}$ sections, which were incubated with collagenase (Sigma-Aldrich; Merck KGaA, Darmstadt, Germany) at $37^{\circ} \mathrm{C}$ for $50-80 \mathrm{~min}$. An equal volume of Dulbecco's modified Eagle's medium (DMEM)/F12 (Hyclone; GE Healthcare Life Sciences, Logan, UT, USA) with $10 \%$ fetal bovine serum (FBS) (Hyclone; GE
Healthcare Life Sciences) was added when no obvious tissue mass was observed. Tissue residues were removed using a 100 -mesh filter and the filtrate was centrifuged at $800 \mathrm{x} \mathrm{g}$, for $5 \mathrm{~min}$ at $4^{\circ} \mathrm{C}$. The pellet was re-suspended in serum-free DMEM/F12 (HyClone; GE Healthcare Life Sciences) and then filtered through a 200-mesh filter. The filtrate was centrifuged at $1,000 \mathrm{x} \mathrm{g}$ for $10 \mathrm{~min}$ at $4^{\circ} \mathrm{C}$ and the supernatant was discarded. The cells were suspended in the DMEM/F12 with 10\% FBS (containing $100 \mathrm{IU} / \mathrm{ml}$ penicillin and $100 \mathrm{IU} / \mathrm{ml}$ streptomycin), seeded in culture flasks and incubated at $37^{\circ} \mathrm{C}$ in $5 \% \mathrm{CO}_{2}$ for $24 \mathrm{~h}$. The DMEM/F12 medium with $10 \% \mathrm{FBS}$ was replaced and cells were cultured at $37^{\circ} \mathrm{C}$ in an incubator with $5 \% \mathrm{CO}_{2}$. The medium was changed every $48 \mathrm{~h}$ and cell growth was measured every day. Once the cells had reached $80-90 \%$ confluence, cells were passaged following a standard procedure.

miRNA transfection. At $24 \mathrm{~h}$ prior to transfection, cells were seeded in 6-well plates at 70-90\% confluency. ESCs were divided into four groups based on transfection: An miR-30c mimics group, a miR-30c inhibitor group, a negative control group (NC) and a blank group. These miRs were purchased from Genepharma Co., Ltd. (Shanghai, China). Lipofectamine ${ }^{\circledR} 2000$ (Invitrogen; Thermo Fisher Scientific, Inc., Waltham, MA, USA) was used for transfection following the manufacturer's instructions. Cells were harvested $48 \mathrm{~h}$ after transfection and reverse transcription-quantitative polymerase chain reaction (RT-qPCR) was performed to detect the expression of miR-30c and PAI-1 in the cells.

RNA extraction and $R T-q P C R$. Total RNA was isolated from tissues using $1 \mathrm{ml} \mathrm{TRIzol}{ }^{\circledR}$ reagent (Invitrogen; Thermo Fisher Scientific, Inc.) per $100 \mathrm{mg}$ tissue according to the manufacturer's protocol. For transfected cells, $2 \times 10^{5}$ cells were treated with $1 \mathrm{ml}$ TRIzol reagent. RNA integrity was checked by gel electrophoresis and the purity of RNA was assessed using the ratio of absorbance at 260 and $280 \mathrm{~nm}$ (Thermo Scientific ${ }^{\mathrm{TM}}$ Evolution 300; Thermo Fisher Scientific, Inc.). Complementary (c)DNA was synthesized from total RNA by reverse transcription with the PrimeScript ${ }^{\mathrm{TM}}$ RT regent kit (Takara Biotechnology, Inc., Dalian, China) and stored at $-20^{\circ} \mathrm{C}$. The $20-\mu 1$ reverse transcription system included $6 \mu 1$ miRNA template, $2 \times 10 \mu 1$ miRNA Reaction Buffer mix, $2 \mu 10.1 \%$ bovine serum albumin (BSA) and $2 \mu \mathrm{l}$ miRNA PrimeScript RT Enzyme Mixture (all Takara Biotechnology, Inc.). The reaction was performed using ABI Veriti 96-Well Thermo Cycler (Thermo Fisher Scientific, Inc.) at $37^{\circ} \mathrm{C}$ for $60 \mathrm{~min}$ with Poly A primer. The SYBR-Green RT-PCR Master mix (Takara Biotechnology, Inc.) was used to detect the expression of miR-30c and PAI-1 in tissues and ESCs. U6 was used as internal reference for detecting miR-30c, while GAPDH was used for PAI-1. The primer sequences were as follows: U6 forward, GCTTCGGCAGCACATATACTAAAAT and reverse, CGCTTCACGAATTTGCGTGTCAT; GAPDH forward, TTAGCACCCCTGGCCAAGG and reverse, CTT ACTCCTTGGAGGCCATG. The primers for miR-30c were 5'-TGTGTAAACATCCTACACTCTCAG-3' and Uni-miR qRT-PCR Primer (Sangon Biotech Co., Ltd., Shanghai China). The primers for PAI-1 were: Forward, 5'-ACCTGGGAATGA CCGACATGT-3' and reverse, 5'-CTCTCGTTCACCTCGAT 
CTTCACT-3'. The miRNA reaction system included $12.5 \mu 1$ SYBR RT-PCR Master mix, $1 \mu$ l forward primer and $1 \mu \mathrm{l}$ reverse primer, $2 \mu \mathrm{l}$ cDNA and $8.5 \mu \mathrm{l}$ double distilled $(\mathrm{dd}) \mathrm{H}_{2} \mathrm{O}$, and the cycling conditions were as follows: $95^{\circ} \mathrm{C}$ for $30 \mathrm{sec}$, followed by 40 cycles of $95^{\circ} \mathrm{C}$ for $5 \mathrm{sec}$ and $60^{\circ} \mathrm{C}$ for $20 \mathrm{sec}$. The PAI-1 system included $10 \mu 1$ SYBR RT-PCR Master mix, $0.5 \mu \mathrm{l}$ forward primer and $0.5 \mu \mathrm{l}$ reverse primer, $1 \mu \mathrm{l} \mathrm{cDNA}$ and $8 \mu \mathrm{ldd} \mathrm{d}_{2} \mathrm{O}$. The PCR cycling conditions were as follows: $95^{\circ} \mathrm{C}$ for $10 \mathrm{~min}$, followed by 40 cycles at $95^{\circ} \mathrm{C}$ for $1 \mathrm{~min}, 60^{\circ} \mathrm{C}$ for $40 \mathrm{sec}, 72^{\circ} \mathrm{C}$ for $30 \mathrm{sec}$ and $72^{\circ} \mathrm{C}$ for $1 \mathrm{~min}$. Relative expression was calculated using the $2^{-\Delta \Delta \mathrm{Cq}}$ method (32).

Western blot analysis. For protein isolation, each 50-mg tissue sample was ground into powder with liquid nitrogen and lysed with $600 \mu \mathrm{l}$ radioimmunoprecipitation assay $(50 \mathrm{mM}$ Tris-base, $1 \mathrm{mM}$ EDTA, $150 \mathrm{mM} \mathrm{NaCl}, 0.1 \%$ SDS, $1 \%$ Triton X-100 and $1 \%$ sodium deoxycholate) lysis buffer. Following centrifugation at the speed of $12,000 \mathrm{xg}$ at $4^{\circ} \mathrm{C}$ for $5 \mathrm{~min}$, the supernatant was obtained and the protein concentration was assessed using Pierce BCA Protein Assay kit. (Thermo Fisher Scientific, Inc.) A similar method was applied to extract proteins in ESCs. Isolated proteins $(10 \mu \mathrm{l})$ were separated by $10 \%$ SDS-PAGE and then transferred to a polyvinylidene difluoride membrane. The proteins were incubated with primary antibodies for $1 \mathrm{~h}$ at room temperature. The primary antibodies were rabbit anti-human PAI-1 (no. 11907; 1:800) and rabbit anti-human GAPDH antibody (no. 2118; 1:2,000). The membranes were then incubated with secondary antibody overnight at $4^{\circ} \mathrm{C}$. The secondary antibody was horseradish peroxidase-conjugated goat anti-rabbit immunoglobulin G (no. 7074; 1:1,000). All antibodies were purchased from Cell Signaling Technology, Inc. (Danvers, MA, USA). Finally, the membrane was developed by enhanced chemiluminescence plus reagent (EMD Millipore, Billerica, MA, USA). Image Lab ${ }^{\mathrm{TM}}$ software (Bio-Rad Laboratories, Inc., Hercules, CA, USA) was applied to analyze the blot images and the intensity of the bands.

Transwell migration assay. The migration assays were performed using Transwell chambers (Corning Inc., New York, NY, USA). The re-suspended ESCs were seeded (1x10 5 cell/well) in $200 \mu \mathrm{l}$ serum-free RPMI 1640 medium (Hyclone; GE Healthcare Life Sciences) and placed into the upper chambers, while the bottom chambers contained $750 \mu 1$ RPMI medium with $10 \%$ FBS. After $48 \mathrm{~h}$ of culture, cells on the lower side of the membrane were fixed with $4 \%$ formaldehyde at room temperature, washed with PBS and stained using crystal violet. Finally, images of the cells were captured under a light microscope at $\mathrm{x} 200$ magnification with five random views and the number of invaded cells was counted.

MTT assay. Four groups of cells transfected with miR-30c mimics, miR-30c inhibitor or negative control as well as blank cells were seeded in 96 -well plates $\left(2 \times 10^{3} /\right.$ well) and 3 replicates were performed for each group. The MTT solution (Beyotime Institute of Biotechnology, Haimen, China) was added to each well at 24, 48, and $72 \mathrm{~h}$. Following incubation at $37^{\circ} \mathrm{C}$ for $4 \mathrm{~h}$, the absorbance of each well was measured using a BioTek spectrophotometer (Biotek Instruments, Inc., Winooski, VT, USA) at $492 \mathrm{~nm}$ and a cell growth curve was constructed.
Cell adhesion assay. In each well of a 96-well plate, $50 \mu 1$ Matrigel (serum-free medium at 1:8 dilution) was added and dried under sterile conditions. Following transfection for $48 \mathrm{~h}$, $2 \times 10^{4}$ cells/well were cultured in each incubated well. After $60 \mathrm{~min}$ of incubation, non-adherent cells were rinsed off and a Cell Counting Kit-8 (Beyotime Company, Jiangsu, China) was used to quantify the attached cells by detection of absorbance at $450 \mathrm{~nm}$ using a BioTek spectrophotometer.

Cell invasion assay. The invasion of ESCs was analyzed using Matrigel invasion chambers (growth-factor depleted Matrigel invasion chambers; BD Biosciences, Franklin Lakes, NJ, USA). In the Matrigel chambers, $500 \mu 1$ serum-free DMEM was added and incubated at room temperature for $1 \mathrm{~h}$ to hydrate the Matrigel. Subsequently, $750 \mu 1$ DMEM containing 20\% fetal bovine serum (Hyclone; GE Healthcare Life Sciences) was added to the lower chamber. Successfully transfected cells were collected and re-suspended to $4 \times 10^{5}$ cells $/ \mathrm{ml}$ with DMEM containing $0.1 \%$ BSA. Following $18 \mathrm{~h}$ of incubation at $37^{\circ} \mathrm{C}$ with $5 \% \mathrm{CO}_{2}$, the cells on the upper side of the membrane were wiped with a cotton swab. The invaded cells on the other side of the chamber were fixed with $4 \%$ methanol at room temperature for $10 \mathrm{~min}$. Following staining with $0.1 \%$ crystal violet, cells were counted under a microscope.

Statistical analysis. Values are expressed as the mean \pm standard deviation. Statistical analysis was performed using SPSS 16 statistical software (SPSS, Inc., Chicago, IL, USA). All data were analyzed using the Student's t-test. $\mathrm{P}<0.05$ was considered to indicate a statistically significant difference.

\section{Results}

Expression of PAI-1 and miR-30c in EMs tissues. RT-qPCR was performed to evaluate the expression of PAI-1 and miR-30c in EMs tissues. PAI-1 expression was significantly increased in ectopic and eutopic endometrium compared with normal tissues $(\mathrm{P}<0.05$; Fig. 1A). PAI-I expression did not significantly differ between ectopic and eutopic endometrium. By contrast, the expression of miR-30c was significantly decreased in ectopic and eutopic endometrium compared with normal tissues $(\mathrm{P}<0.05)$; however, no difference in miR-30c expression was observed between ectopic and eutopic endometrium (Fig. 1B). In addition, the levels of PAI-1 protein in tissues were detected by western blot analysis and were similar to its mRNA expression. Levels of PAI-1 protein were significantly higher in eutopic and ectopic endometrium than in normal tissues $(\mathrm{P}<0.05)$, while there was no significant difference between PAI-1 expression in ectopic and eutopic endometriosis tissue (Fig. 1C). These results demonstrated that miR-30c expression was decreased, whereas PAI-1 expression was increased in EMs tissue.

miR-30c inhibits the expression of PAI-1 in transfected ESC cells. To determine whether PAI-1 expression is regulated by miR-30c, ESCs were transfected with miR-30c mimics and miR-30c inhibitor. Following transfection for $48 \mathrm{~h}$, miR-30c expression was significantly increased in ESCs transfected with miR-30c mimics and was $>70 \%$ higher than that in the NC and Blank groups $(\mathrm{P}<0.05$ vs. Blank; Fig. 2A). Furthermore, miR-30c 
A

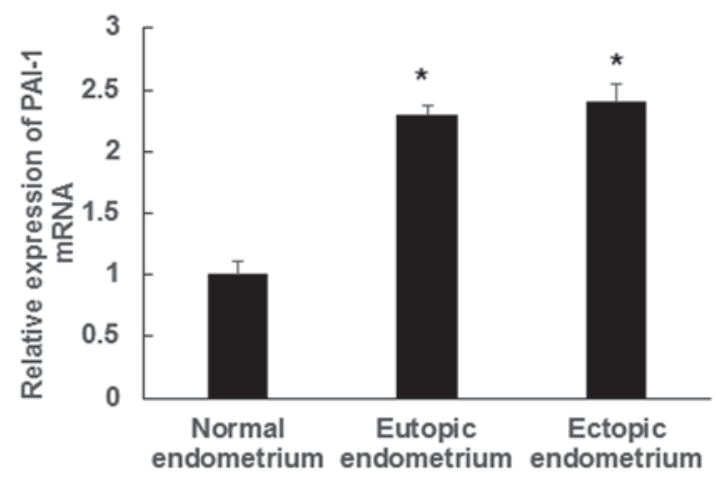

C

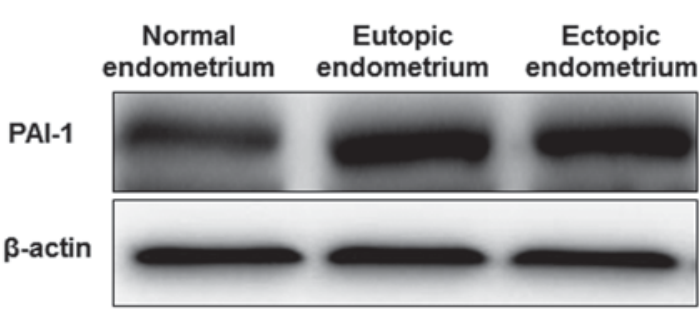

B
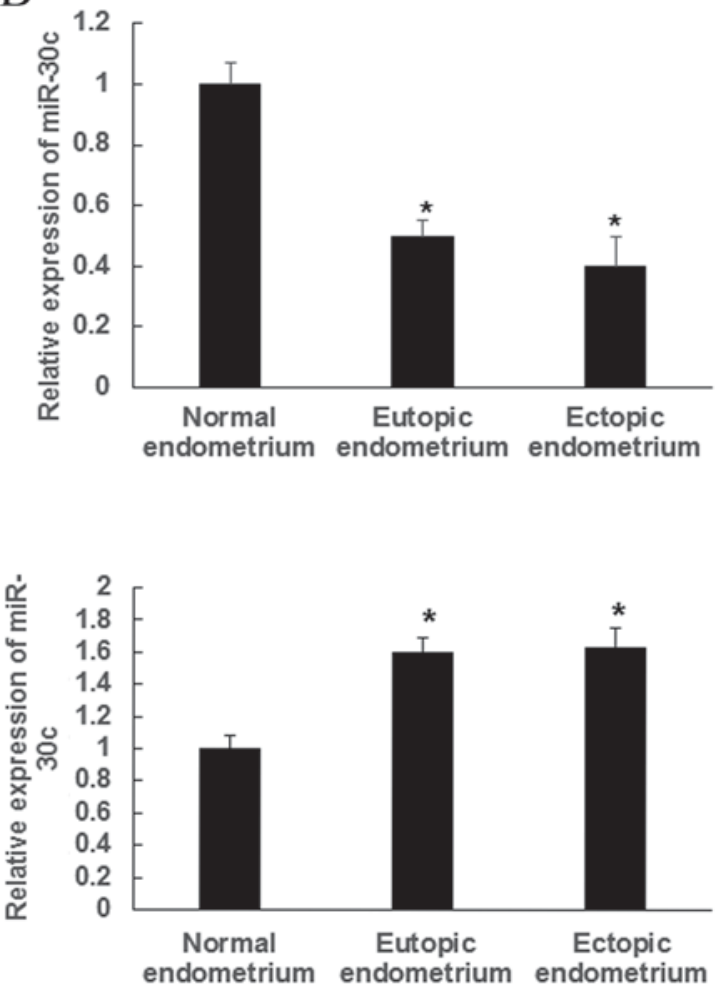

Figure 1. The expression of PAI-1 and miR-30c in endometrial tissues. (A) Reverse transcription-quantitative polymerase chain reaction demonstrated that levels of PAI-1 mRNA were increased in eutopic and ectopic endometrial tissues compared with normal tissues. (B) miR-30c mRNA expression was also decreased in eutopic and ectopic endometrial tissues compared with normal tissues. (C) Western blot analysis indicated that PAI-1 expression was increased in eutopic and ectopic endometrial tissues compared with normal tissues. ${ }^{*} \mathrm{P}<0.05$ vs. normal endometrium. ESCs, primary endometrial stromal cells; miR, microRNA; PAI-1, plasminogen activator inhibitor type 1.

expression was significantly decreased in ESCs transfected with miR-30c inhibitor and was $\sim 30 \%$ of that in the NC and Blank groups ( $\mathrm{P}<0.001$ vs. Blank; Fig. 2A). Total RNA and protein was extracted from transfected ESCs to detect the expression of PAI-1 mRNA and protein by RT-qPCR and western blotting, respectively. Compared with the $\mathrm{NC}$ and Blank groups, cells transfected with miR-30c mimics exhibited significantly decreased expression of PAI-1 at the mRNA ( $<<0.05$; Fig. 2B) and protein level $(\mathrm{P}<0.05$; Fig. $2 \mathrm{C})$. By contrast, inhibition of miR-30c expression increased the expression of PAI-1 at the mRNA and protein level ( $\mathrm{P}<0.05$; Fig. $2 \mathrm{~B}$ and $\mathrm{C})$. These results indicated that overexpression of miR-30c may repress the expression of PAI-1 mRNA and protein.

ESC proliferation, adhesion and migration are regulated by $m i R-30 c$. To further assess the regulatory roles of miR-30c in ESCs, its effect on migration and invasion were assessed. Compared with the Blank and NC groups, ESCs overexpressing miR-30c exhibited significantly reduced cell migration $(\mathrm{P}<0.05$; Fig. 3A) and invasion $(\mathrm{P}<0.05$; Fig. 3B). By contrast, inhibition of miR-30c expression in ESCs increased the ability of cells to migrate and invade $(\mathrm{P}<0.05$; Fig. $3 \mathrm{~A}$ and $\mathrm{B})$. These results indicated that miR-30c expression inhibits the motility of ESCs.

To elucidate the effect of miR-30c on cell proliferation, an MTT assay was performed. The results demonstrated that, compared with the Blank and NC groups, overexpression of miR-30c in ESCs significantly reduced the proliferation of ESCs $(\mathrm{P}<0.05)$, whereas inhibition of miR-30c in ESCs significantly increased ESC proliferation ( $\mathrm{P}<0.05$; Fig. $3 \mathrm{C})$. This suggested that miR-30c may repress the proliferation of ESCs.

Compared with the Blank and NC groups, the results of an adhesion test using Matrigel showed that overexpression of miR-30c in the miR-30 mimics group decreased the number of adhesive cells, while the inhibition of miR-30c in the group transfected with the miR-30 inhibitor exhibited an increased number of adhesive cells (Fig. 3D). This indicated that miR-30c may reduce the adhesion ability of ESCs.

\section{Discussion}

EMs is a type of benign disease with malignant behaviors (33). The pathology of EMs includes adhesion of ectopic endometrial cells, invasive growth and angiogenesis $(34,35)$. The etiology and pathogenesis of EMs have remained to be fully elucidated. miRNA, as a post-transcriptional regulator, may influence the biological behavior of cells by targeting a wide range of mRNAs (36). Accounting for $2 \%$ of the total number of human genes, miRNA can regulate $>30 \%$ genes in the human genome (37). It is important to identify miRNA and associated target genes that impact EMs progression. As the primary inhibitor of the fibrinolysis system, PAI-1 is widely expressed in various tissues. Casslen et al (38) found that PAI-1 was expressed in the human endometrium and Bruse et al (39) demonstrated that PAI-1 was overexpressed in ectopic 
A

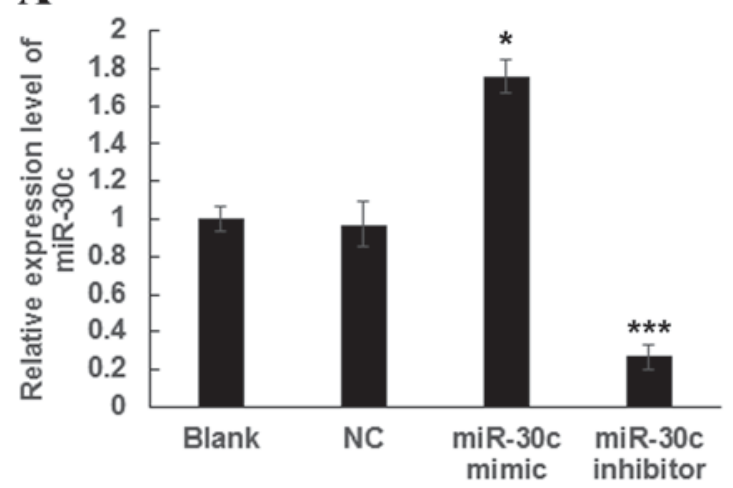

C

PAI-1

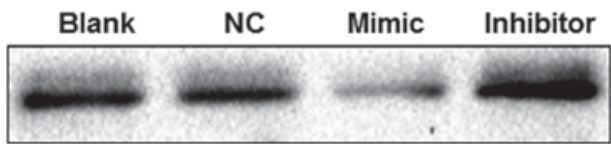

$\beta$-actin

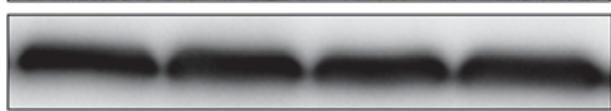

B
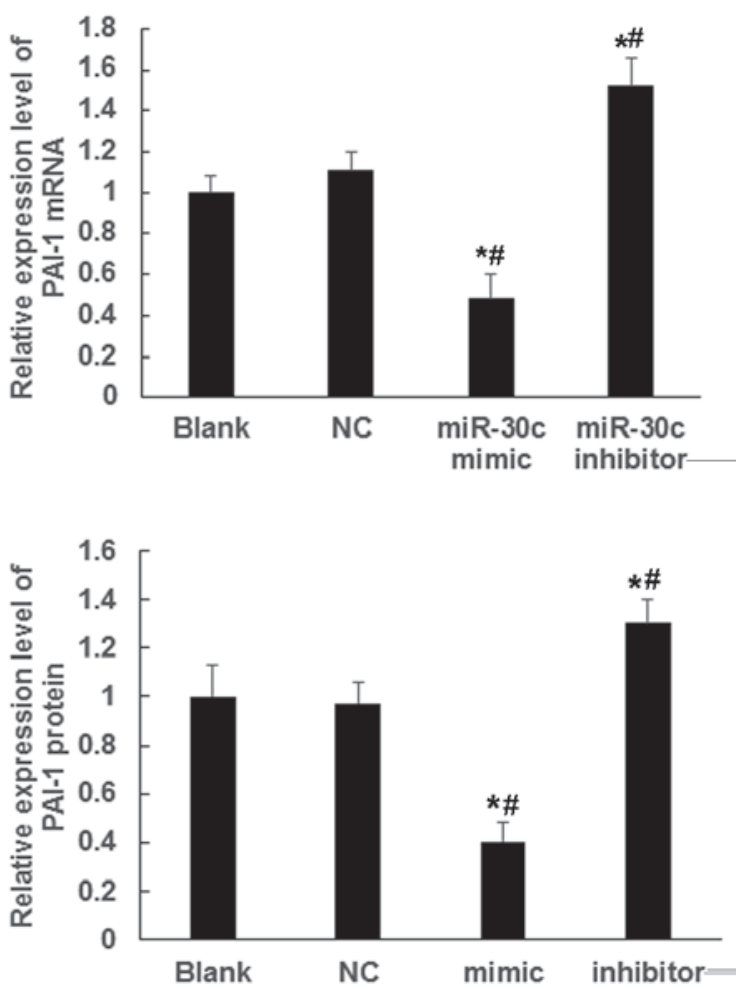

Figure 2. miR-30c represses the transcription and translation of PAI-1 in ESCs. (A) ESCs were transiently transfected with miR-30c mimic or inhibitor and expression of miR-30c was detected by RT-qPCR after $48 \mathrm{~h}$. (B) RT-qPCR was performed to detect PAI-1 mRNA in ESCs following transfection of miR-30c or inhibitor. (C) Western blot analysis was performed to detect levels of PAI-1 protein in ESCs following transfection of miR-30c or inhibitor. " $\mathrm{P}<0.05,{ }^{* * * *} \mathrm{P}<0.001$ compared with blank; ${ }^{*} \mathrm{P}<0.05$, compared with NC. ESCs, primary endometrial stromal cells; RT-qPCR, reverse-transcription quantitative polymerase chain reaction; NC, negative control; miR, microRNA; PAI-1, plasminogen activator inhibitor type 1.

A
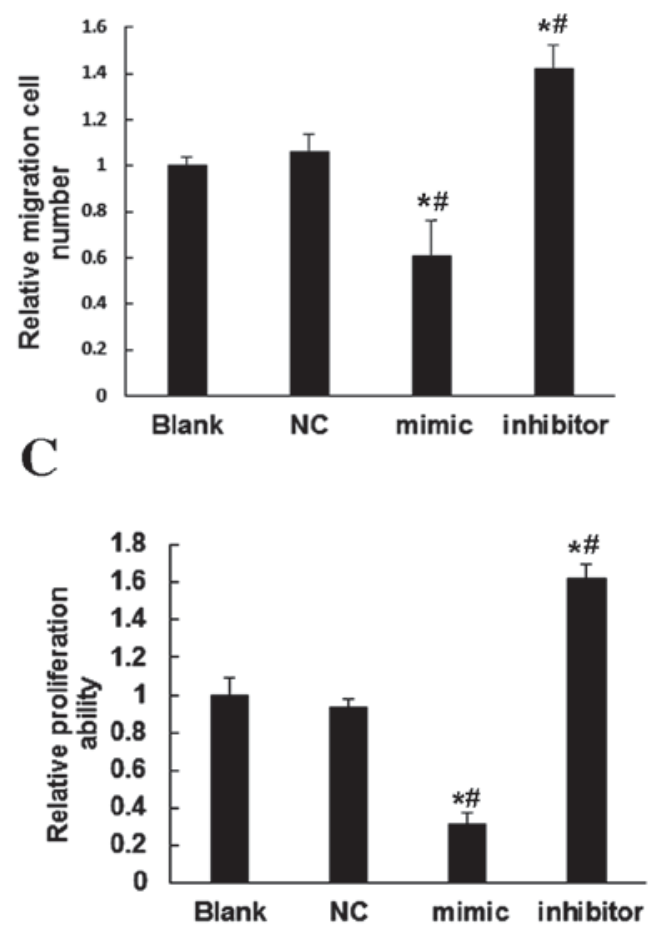

B
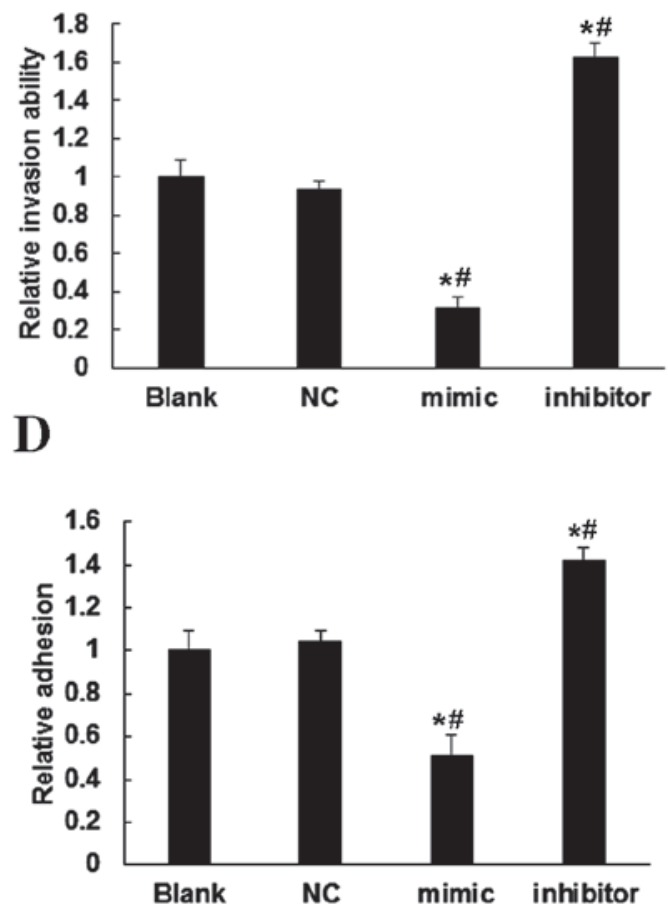

Figure 3. miR-30c inhibits the migration, invasion, proliferation and adhesion of endometrial stromal cells. Effects of miR-30c on (A) cell migration and (B) invasion were analyzed by a Transwell invasion assay. (C) Effects of miR-30c on cell proliferation were analyzed using an MTT assay. (D) Effects of miR-30c on cell adhesion were analyzed using a Cell Counting Kit- 8 assay. ${ }^{*} \mathrm{P}<0.05$, compared with blank; ${ }^{*} \mathrm{P}<0.05$, compared with NC. NC, negative control; miR, microRNA. 
endometrial tissues. The results of the present study showed that PAI-1 expression in ectopic and eutopic endometrial tissues was higher than in normal tissues, which is consistent with the results of the previous study by Bruse et al (39).

A study by Lagos-Quintana et al (40) detected the expression of miR-30c in the heart and brain tissues of mice. Furthermore, abnormal expression of miR-30c was found in the reticulocytes of patients with Polycythemia vera (41). Downregulated miR-30c has been identified in a number of malignancies, including breast (42), colorectal (43) and bladder cancer (44). The present study found that miR-30c was downregulated in ectopic and eutopic endometrial tissues, indicating that miR-30c may suppress the progression and development of EMs. Primary ESCs were cultured and subsequently transfected with miR-30c mimics or inhibitor. It was demonstrated that miR-30c was able to regulate the expression of PAI-1 in ESCs. It has been demonstrated that miR-30c can directly bind to the bases 1,704-1,760 in the 3'untranslated region (UTR) of PAI-1 in human endothelial cells (13). Therefore, miR-30c may regulate PAI-1 expression by directly targeting the 3'UTR of PAI-1. In the present study, the biological functions of miR-30c in ESCs were investigated by targeting PAI-1. It was demonstrated that repressed expression of PAI-1 induced by increased miR-30c expression may decrease the migration and invasion of ESCs. Furthermore, inhibition of miR-30c expression induced the upregulation of PAI-1 expression and promoted ESC migration and invasion. In addition, the MTT assay showed that miR-30c inhibited ESC proliferation. The effects of miR-30c on the adhesion ability of ESCs were also examined. It was found that overexpression of miR-30c downregulated PAI-1 expression, thus reducing the number of cells attached to the Matrigel, while inhibition of miR-30c increased the number of adhesive cells by upregulating the expression of PAI-1. The results suggested that miR-30c may be involved in endometriosis by targeting PAI-1, thus affecting the migration, invasion, proliferation and adhesion of ESCs.

In conclusion, the present study demonstrated that downregulation of miR-30c may be involved in the occurrence and progression of EMs. The negative regulation of PAI-1 by miR-30c appears to be important in Ems-associated processes. Through designing targeted inhibition strategies and monitoring the expression of miR-30c and PAI-1, the diagnosis and prognosis of Ems may improve.

\section{Acknowledgements}

The authors would like to thank Professor Li Xu (Vice President of The Affiliated Hospital of Jining Medical University) for providing the experimental materials and her advice and Professor Weihua Wu (The Office of President) for his experimental suggestions and thesis modification. The authors also wish to thank Professor Hongchun Hou (Department of Reproductive Medicine, The Affiliated Hospital of Jining Medical University) for his kind help during the present study.

\section{References}

1. Parazzini F, Vercellini P and Pelucchi C: Endometriosis: Epidemiology and etiological factors. Endometriosis: Science and Practice. Wiley-Blackwell, New York, NY, pp19-26, 2012.
2. Tandoi I, Somigliana E, Riparini J, Ronzoni S, Vigano' P and Candiani M: High rate of endometriosis recurrence in young women. J Pediatr Adolesc Gynecol 24: 376-379, 2011.

3. Vercellini P, Frontino G, Pietropaolo G, Gattei U, Daguati R and Crosignani PG: Deep endometriosis: Definition, pathogenesis, and clinical management. J Am Assoc Gynecol Laparosc 11: 153-161, 2004.

4. Vercellini P, Viganò P, Somigliana E and Fedele L: Endometriosis: Pathogenesis and treatment. Nat Rev Endocrinol 10: 261-275, 2014.

5. Lai EC, Tomancak P, Williams RW and Rubin GM: Computational identification of Drosophila microRNA genes. Genome Biol 4: R42, 2003.

6. Kim VN: Small RNAs: Classification, biogenesis, and function. Mol Cells 19: 1-15, 2005.

7. Pasquinelli AE: MicroRNAs and their targets: Recognition, regulation and an emerging reciprocal relationship. Nat Rev Genet 13: 271-282, 2012.

8. Rácz Z, Kaucsár T and Hamar P: The huge world of small RNAs: Regulating networks of microRNAs (review). Acta Physiol Hung 98: 243-251, 2011

9. Schickel R, Boyerinas B, Park SM and Peter ME: MicroRNAs: Key players in the immune system, differentiation, tumorigenesis and cell death. Oncogene 27: 5959-5974, 2008.

10. Bueno MJ, de Castro IP and Malumbres M: Control of cell proliferation pathways by microRNAs. Cell Cycle 7: 3143-3148, 2008.

11. Chegini N: Uterine microRNA signature and consequence of their dysregulation in uterine disorders. Anim Reprod 7: 117-128, 2010.

12. Pan Q and Chegini N: MicroRNA signature and regulatory functions in the endometrium during normal and disease states. Semin Reprod Med 26: 479-493, 2008.

13. Patel N, Tahara S, Malik P and Kalra VK: Involvement of miR-30c and miR-301a in immediate induction of plasminogen activator inhibitor-1 by placental growth factor in human pulmonary endothelial cells. Biochem J 434: 473-482, 2011.

14. Divakaran V and Mann DL: The emerging role of microRNAs in cardiac remodeling and heart failure. Circ Res 103: 1072-1083, 2008.

15. Karbiener M, Neuhold C, Opriessnig P, Prokesch A, Bogner-Strauss JG and Scheideler M: MicroRNA-30c promotes human adipocyte differentiation and co-represses PAI-1 and ALK2. RNA Biol 8: 850-860, 2011.

16. Xia Y, Chen Q, Zhong Z, Xu C, Wu C, Liu B and Chen Y: Down-regulation of miR-30c promotes the invasion of non-small cell lung cancer by targeting MTA1. Cell Physiol Biochem 32: 476-485, 2013.

17. Gong J, Liu R, Zhuang R, Zhang Y, Fang L, Xu Z, Jin L, Wang T, Song C, Yang K, et al: miR-30c- $1^{*}$ promotes natural killer cell cytotoxicity against human hepatoma cells by targeting the transcription factor HMBOX1. Cancer Sci 103: 645-652, 2012.

18. Zhou H, Xu X, Xun Q, Yu D, Ling J, Guo F, Yan Y, Shi J and $\mathrm{Hu}$ Y: microRNA-30c negatively regulates endometrial cancer cells by targeting metastasis-associated gene-1. Oncol Rep 27: 807-812, 2012

19. Gils A and Declerck PJ: The structural basis for the pathophysiological relevance of PAI-I in cardiovascular diseases and the development of potential PAI-1 inhibitors. Thromb Haemost 91: 425-437, 2004.

20. Yasar Yildiz S, Kuru P, Toksoy Oner E and Agirbasli M: Functional stability of plasminogen activator inhibitor-1. ScientificWorldJournal 2014: 858293, 2014.

21. Zhou A, Huntington JA, Pannu NS, Carrell RW and Read RJ: How vitronectin binds PAI-1 to modulate fibrinolysis and cell migration. Nat Struct Biol 10: 541-544, 2003.

22. Wind T, Hansen M, Jensen JK and Andreasen PA: The molecular basis for anti-proteolytic and non-proteolytic functions of plasminogen activator inhibitor type-1: Roles of the reactive centre loop, the shutter region, the flexible joint region and the small serpin fragment. Biol Chem 383: 21-36, 2002.

23. Cesari M, Pahor M and Incalzi RA: Plasminogen activator inhibitor-1 (PAI-1): A key factor linking fibrinolysis and age-related subclinical and clinical conditions. Cardiovasc Ther 28: e72-e91, 2010.

24. Fay WP, Eitzman DT, Shapiro AD, Madison EL and Ginsburg D: Platelets inhibit fibrinolysis in vitro by both plasminogen activator inhibitor-1-dependent and-independent mechanisms. Blood 83: 351-356, 1994.

25. Kozlova N, Jensen JK, Chi TF, Samoylenko A and Kietzmann T: PAI-1 modulates cell migration in a LRP1-dependent manner via $\beta$-catenin and ERK1/2. Thromb Haemost 113: 988-998, 2015. 
26. Czekay RP, Wilkins-Port CE, Higgins SP, Freytag J, Overstreet JM, Klein RM, Higgins CE, Samarakoon R and Higgins PJ: PAI-1: An integrator of cell signaling and migration. Int J Cell Biol 2011: 562481, 2011.

27. Placencio VR, Miyata T and DeClerck YA: Pharmacologic inhibition of PAI-1 increases apoptosis and inhibits macrophage migration in cancer. Cancer Research 73: Abstract 1548, 2013.

28. Loskutoff DJ, Curriden SA, Hu G and Deng G: Regulation of cell adhesion by PAI-1. Apmis 107: 54-61, 1999.

29. Lee CC and Huang TS: Plasminogen activator inhibitor-1: The expression, biological functions, and effects on tumorigenesis and tumor cell adhesion and migration. J Cancer Mole 1: 25-36, 2005.

30. Erem C, Ersoz HO, Karti SS, Ukinç K, Hacihasanoglu A, Değer $\mathrm{O}$ and Telatar $\mathrm{M}$ : Blood coagulation and fibrinolysis in patients with hyperthyroidism. J Endocrinol Invest 25: 345-350, 2002.

31. Binder BR, Christ G, Gruber F, Grubic N, Hufnagl P, Krebs M, Mihaly $\mathrm{J}$ and Prager GW: Plasminogen activator inhibitor 1: Physiological and pathophysiological roles. News Physiol Sci 17: 56-61, 2002

32. Livak KJ and Schmittgen TD: Analysis of relative gene expression data using real-time quantitative PCR and the 2 (-Delta Delta C (T)) method. Methods 25: 402-408, 2001

33. Somigliana E, Vigano' P, Parazzini F, Stoppelli S, Giambattista E and Vercellini P: Association between endometriosis and cancer: A comprehensive review and a critical analysis of clinical and epidemiological evidence. Gynecol Oncol 101: 331-341, 2006.

34. Witz CA: Current concepts in the pathogenesis of endometriosis. Clin Obstet Gynecol 42: 566-585, 1999.

35. Laschke MW and Menger MD: In vitro and in vivo approaches to study angiogenesis in the pathophysiology and therapy of endometriosis. Hum Reprod Update 13: 331-342, 2007.
36. Friedman RC, Farh KK, Burge CB and Bartel DP: Most mammalian mRNAs are conserved targets of microRNAs. Genome Res 19: 92-105, 2009.

37. Lewis BP, Burge CB and Bartel DP: Conserved seed pairing, often flanked by adenosines, indicates that thousands of human genes are microRNA targets. Cell 120: 15-20, 2005.

38. Casslen B, Urano S and Ny T: Progesterone regulation of plasminogen activator inhibitor 1 (PAI-1) antigen and mRNA levels in human endometrial stromal cells. Thromb Res 66: 75-87, 1992.

39. Bruse C, Radu D and Bergqvist A: In situ localization of mRNA for the fibrinolytic factors UPA, PAI-1 and UPAR in endometriotic and endometrial tissue. Mol Hum Reprod 10: 159-166, 2004

40. Lagos-Quintana M, Rauhut R, Yalcin A, Meyer J, Lendeckel W and Tuschl T: Identification of tissue-specific microRNAs from mouse. Curr Biol 12: 735-739, 2002.

41. Bruchova H, Merkerova M and Prchal JT: Aberrant expression of microRNA in polycythemia vera. Haematologica 93: 1009-1016, 2008.

42. Tanic M, Yanowsky K, Rodriguez-Antona C, Andrés R Márquez-Rodas I, Osorio A, Benitez J and Martinez-Delgado B: Deregulated miRNAs in hereditary breast cancer revealed a role for miR-30c in regulating KRAS oncogene. PloS One 7: e38847, 2012.

43. Bandrés E, Cubedo E, Agirre X, Malumbres R, Zárate R, Ramirez N, Abajo A, Navarro A, Moreno I, Monzó M and García-Foncillas J: Identification by real-time PCR of 13 mature microRNAs differentially expressed in colorectal cancer and non-tumoral tissues. Mol Cancer 5: 29, 2006.

44. Wang G, Zhang H, He H, Tong W, Wang B, Liao G, Chen Z and Du C: Up-regulation of microRNA in bladder tumor tissue is not common. Int Urol Nephrol 42: 95-102, 2010. 